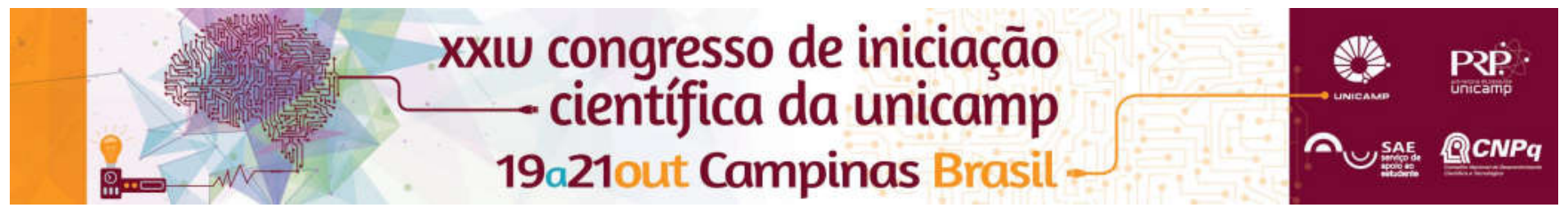

\title{
A Crítica de Durandus de St. Pourçain à Teoria da Abstração de Tomás de Aquino
}

Autora: Maria Clara Pereira e Silva (IC)*

Orientador: Prof. Dr. Márcio Augusto Damin Custódio.

\section{Resumo}

O objetivo desta pesquisa é mapear a crítica de Durandus de St. Pourçain à teria da abstração de Tomás de Aquino. Para tanto, dediquei-me à análise da noção de relação no interior do Comentário às Sentenças de Pedro Lombardo I, d.3, q. 5 e II, d.3, q. 5 [A] [C] de Durandus.

\author{
Palavras-chave \\ Cognição, intelecto, relação.
}

\section{Introdução}

Durandus de St. Pourçain (1270/5-1334) é considerado o primeiro anti-tomista dominicano. Sua produção intelectual, não só afetou a produção de seus contemporâneos, mas impactou diretamente o cenário posterior da filosofia medieval. O que é atestado pelo fato de as teorias de Durandus terem sido objeto de estudo na cátedra de nominalismo na Universidade de Salamanca no séc. XV. Além do fato de ser considerado, juntamente a Pedro de Auriol (1280-1322), predecessor de Guilherme de Occam (1285-1347). Já entre seus contemporâneos dominicanos, principalmente seu mentor Hervaeus Natalis (1260-1323), suas teorias foram alvos de grandes críticas. Isto porque as definições de Durandus sobre relação, essência e trindade (entre outas noções) entraram em conflito com o Capítulo Geral reformulado em 1309 que conformava a ordem os Frades Pregadores à doutrina tomista. $\mathrm{O}$ que pode ser atestado pelo fato de Natalis ter escrito um Quodlibetal em resposta ao Comentário $[A]$ de Durandus, inaugurando assim as profícuas discussões entre os dois dominicanos. A noção de relação, foi eleita como objeto desta pesquisa, visto que é aquela que diz respeito à teoria da cognição e pode representar uma diferença entre o pensamento de Durandus se comparado ao pensamento de Tomás de Aquino.

\section{Resultados e Discussão}

Para Durandus, quando o intelecto opera por meio de um ato cognitivo, nenhuma entidade absoluta é adicionada a ele. A cognição, ou pensamento, é tratada pelo autor como uma entidade relativa e não como algo que o intelecto possui, ou que é adicionado a ele de maneira real. Nessa medida, a cognição é entendida como o modo pelo qual o poder cognitivo se relaciona com outras coisas que não ele mesmo. Ao determinar sua noção de relação, Durandus sustenta um processo de cognição independente de espécies inteligíveis, universais e intelecto agente, conceitos determinantes para a sustentação do processo de cognição determinado por Tomás de Aquino. Ao determinar a noção de relação e negar os pressupostos necessários para a sustentação de uma teoria cognitiva baseada no processo de abstração Durandus sustenta uma teoria cognitiva inovadora

\section{Conclusões}

Os pressupostos teóricos da teoria cognitiva de Tomás de Aquino, as espécies inteligíveis, universais e intelecto agente, não cabem na teoria da cognição de Durandus. $O$ complexo processo de conhecimento, que envolvia vários órgãos corpóreos e não corpóreos e afirmava a existência e a necessidade de abstração é simplificado ao máximo, e é entendido como uma relação entre a especulação e os especuláveis. Isto porque, Durandus admite que o intelecto fica diante da coisa no mundo, e o conhecimento se dá por intermédio de uma relação entre o intelecto e o objeto de seu conhecimento. Nessa medida, é próprio do intelecto conhecer e, estando diante da coisa, ele o faz.

\section{Agradecimentos}

Agradeço à instituição CNPQ que incentivou a minha iniciação científica e concedeu-me uma bolsa de estudos, sem a qual este trabalho não poderia ter sido realizado. Agradeço, também, ao meu orientador Prof. Dr. Márcio Augusto Damin Custódio que acreditou em mim e me orientou desde o meu primeiro semestre de graduação. Por fim, sou grata pela amizade e pelos ensinamentos dos integrantes do Grupo de Pesquisa Metafísica e Política.

\section{REFERÊNCIAS}

AQUINO, Tomás de. Scriptum Super Libros Sententiarum Magistri Petri Lombardi. Ed.P. Mandonnet Vol. 1-2, Parisiis: P. Lethielleux, 1929.

POURÇAIN, Durandus de St.; In Petri Lombardi Sententias Theologicas Commentarium libri IIII. Venice, 1571; repr. Ridgewood, NJ: The Gregg Press, 1964.

HARTMAN, Peter John. Durand of St.-Pourçain on Cognitive Acts: Their Cause,Ontological Status, and Intentional Character. 2012. [280 f.] Tese de doutorado. Centre for Medieval Studies, University of Toronto, Toronto.

IRIBARREN, Isabel. Durandus of St. Pourçain: A Dominican Theologian in the shadow of Aquinas. Oxford: Oxford University Presse, 2005.

LOWE, Elizabeth. The Contested Theological Authority of Thomas Aquinas. The controversies between Hervaeus Natalis and Durandus of St. Pourçain. Routledge New Your \& London, 2003. 